\title{
Research on the Small Span Bridge Reconstruction and Expansion Technology
}

\author{
Rishuang SUN \\ School of Highway, Chang' an University \\ Xi'an 710064, Shanxi, China \\ Shandong Provincial Communications Planning and Design \\ Institute, Jinan 250031, China \\ E-mail: handsomepb@126.com \\ Xufei JIAO \\ Shandong Provincial Communications Planning and Design \\ Institute, Jinan 250031, China \\ E-mail: 24384046@qq.com
}

\author{
Lei WANG \\ Shandong Provincial Communications Planning and Design Institute \\ Jinan 250031, China \\ E-mail: 48834702@qq.com
}

\begin{abstract}
The research was performed on the background of reconstruction and expansion project of Shandong $1^{\#}$ expressway, contrastive analyzed the changing status of Highway Engineering Technique Standard in regard to the bridge load revision adjustment, particularly computational analyzed the technical requirement and usability of the existing bridge. Combined the analysis of bridge detection and evaluation results, the reconstruction and expansion technology of the existing bridge was theoretical calculated and discussed. Finally, the reconstruction and expansion technical method and suggestion on the mechanical behavior changing character of the small span upper beam-slab and the bottom abutment were proposed. The instance analysis showed that, the small span bridge reconstruction and expansion technology has the advantage of economically feasible, environment protecting and technology feasible. Its specialty of short construction period, small effects, convenient for keeping traffic and meeting the demand of basic functions enables it with a large popularize prospect.
\end{abstract}

Keywords-technical standard; bridge load; reconstruction and expansion

\section{RESEARCH BACKGROUND}

In order to apply the develop of highway traffic, the Ministry of Transport scheduled the revision of Highway Engineering Technique Standard (JTG B01-2003) in 2011, and the Highway Engineering Technique Standard (JTG B01-2014) was implemented from 1st Apr. 2015. This revision work summarized the latest highway construction experience in our country systematically, and fully absorbed the highway industry scientific research achievements in recent years, learned the relevant standard and the advanced technology from foreign developed country. It fully reflects the traffic development request of "comprehensive, wisdom, green and peace". The revision protects the environment, saves resources and highlights the function of the highway and its facilities in determining the role of technical standards and indicators on the premise of safety. The Highway Engineering Technique Standard (JTG B01-2014) revised, adjusted and supplemented the bridge load, and the revision increased the regulations and requirements of safety evaluation, especially the influence of implementation process of highway reconstruction and expansion on the detection evaluation, safety evaluation and technical characteristic of the existing bridge.

\section{A. Bridge Load}

Calculated span: the arranging support is the adjacent supports' horizontal distance; No support is the horizontal distance between the centre cross the upper and lower structure.

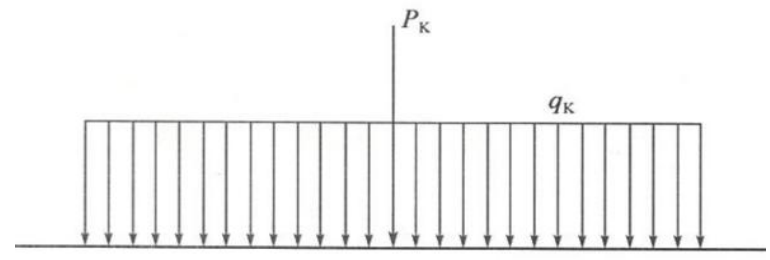

Figure 1. Lane load

TABle I. The Main TeChnical Parameters of The Vehicle LOAD

\begin{tabular}{c|c|c}
\hline Item & Unit & $\begin{array}{c}\text { Technical } \\
\text { parameter }\end{array}$ \\
\hline Gravity standard of vehicle & $\mathrm{kN}$ & 550 \\
\hline Gravity standard of the front axle & $\mathrm{kN}$ & 30 \\
\hline Gravity standard of the central axle & $\mathrm{kN}$ & $2 \times 120$ \\
\hline Gravity standard of the rear axle & $\mathrm{kN}$ & $2 \times 140$ \\
\hline Wheel tread & $\mathrm{m}$ & $3+1.4+7+1.4$ \\
\hline Wheelbase & $\mathrm{m}$ & 1.8 \\
\hline $\begin{array}{c}\text { The landing width and length of the } \\
\text { front wheel }\end{array}$ & $\mathrm{m}$ & $0.3 \times 0.2$ \\
\hline $\begin{array}{c}\text { The landing width and length of the } \\
\text { middle and rear wheel }\end{array}$ & $\mathrm{m}$ & $0.6 \times 0.2$ \\
\hline $\begin{array}{c}\text { Vehicle boundary dimension (length } \\
\times \text { width) }\end{array}$ & $\mathrm{m}$ & $15 \times 2.5$ \\
\hline \begin{tabular}{c} 
(a) \\
\hline
\end{tabular} & & \\
\hline
\end{tabular}




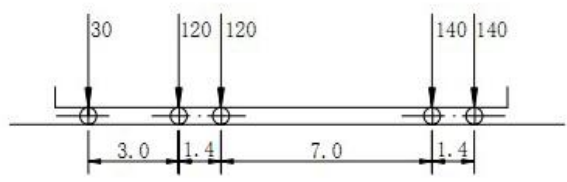

(a) elevation

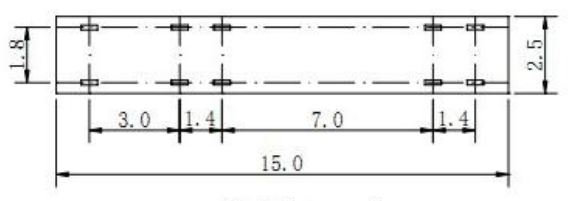

(b) ichnography

Figure 2. The arrangement diagram of the vehicle load

\section{B. Highway Engineering Technique Standard(TG B01- 2003)}

The grade I highway lane-load uniformly distributed load standard value $=10.5 \mathrm{kn} / \mathrm{m}$. The concentrated load standard value was selected according to the following provisions:

When the bridge and culvert span $\leq 5 \mathrm{~m},=180 \mathrm{kN}$;

When the bridge and culvert span $\geq 50 \mathrm{~m},=360 \mathrm{kN}$;

When the bridge and culvert span $>5 \mathrm{~m}$, <50m, was obtained through interpolation. When calculating the shear effect, the coefficient of concentrated load standard values should be multiplied by 1.2 .

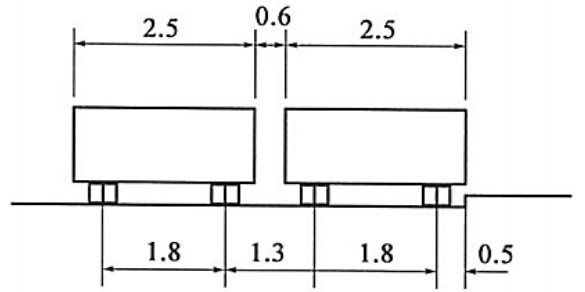

Figure 3. The lateral arrangement diagram of the vehicle load

\section{Highway Engineering Technique Standard(JTG B01- 2014)}

The grade I highway lane-load uniformly distributed load standard value $=10.5 \mathrm{kn} / \mathrm{m}$. The concentrated load standard value was selected according to the following provisions:

When the bridge and culvert span $\leq 5 \mathrm{~m},=270 \mathrm{kN}$;

When the bridge and culvert span $\geq 50 \mathrm{~m},=360 \mathrm{kN}$;

When the bridge and culvert span $>5 \mathrm{~m},<50 \mathrm{~m}$, was obtained through interpolation. When calculating the shear effect, the coefficient of concentrated load standard values should be multiplied by 1.2 .

\section{Revision Adjustment Results}

According to the seriously reading and analysis of the <standard>, It is not hard to see about the revision of the motor load will adjust mainly concentrated load standard values are increased by $50 \%$. For uniformly distributed load, the standard model, design, number of lanes, horizontal lanes load coefficient, vertical reduction factor, the crowd load standard values are not adjusted.

\section{ENGINEERING EXAMPLES}

\section{A. General Situation}

Shandong $1^{\#}$ expressway's total length is $318 \mathrm{~km}$, was built in the 1890s, and it open to traffic has been nearly 15 years, its roadbed width is $26 \mathrm{~m}$, its design speed is $120 \mathrm{~km} / \mathrm{h}$, the original bridge design load is steam-20, the calculation load is hang-120. Precast large bridge, structure is given priority to bridge, tin, and channels, $17 \%$ of the total mileage. Transform the success of this kind of Bridges and channels to a great extent will influences the whole project construction schedule and technology control.

TABLE II. Statistical ANALYSIS OF BRIDGE ChanNELS

\begin{tabular}{c|c|c|c|c}
\hline Type & Span & Substructure & number & $\begin{array}{c}\text { Account for } \\
\text { all } \\
\text { installations }\end{array}$ \\
\hline \multirow{2}{*}{$\begin{array}{c}\text { Solid } \\
\text { slab }\end{array}$} & $5 \mathrm{~m}$ & $\begin{array}{c}\text { Thin-walled platform/ } \\
\text { Gravity platform }\end{array}$ & 132 & $13.3 \%$ \\
\cline { 2 - 5 } & $6 \mathrm{~m}$ & $\begin{array}{c}\text { Thin-walled platform/ } \\
\text { Gravity platform }\end{array}$ & 158 & $15.9 \%$ \\
\hline \multirow{2}{*}{$\begin{array}{c}\text { hollow } \\
\text { slab }\end{array}$} & $8 \mathrm{~m}$ & $\begin{array}{c}\text { Thin-walled platform/ } \\
\text { Gravity platform }\end{array}$ & 258 & $26.0 \%$ \\
\cline { 2 - 5 } & $10 \mathrm{~m}$ & $\begin{array}{c}\text { Thin-walled platform/ } \\
\text { Gravity platform }\end{array}$ & 94 & $9.5 \%$ \\
\hline
\end{tabular}

B. Detection and Evaluation Results

1259 single width bridges were detected, including 40 long span bridges, 99 middle span bridges and 1120 small bridge channels.

The ranking result of general technology state is: class 1 is 39 , with the ratio of $3.10 \%$; class 2 is 657 , with the ratio of $52.18 \%$; class 3 is 561 , with the ratio of $44.56 \%$; class 4 is 2 , with the ratio of $0.16 \%$; class 5 is 0 , with the ratio of $0.00 \%$.

The main disease form of reinforced concrete hollow (solid) plate and prestressed concrete hollow slab is: transverse cracks of plate wing, vertical cracks, saltpetering, concrete corrosion; transverse cracks of web, vertical cracks, corrosion of reinforcement; transverse cracks of baseboard, longitudinal crack, porous saltpetering, corrosion expansion and exposion of reinforcing bars, the honeycomb pitting surface of concrete and local damage.

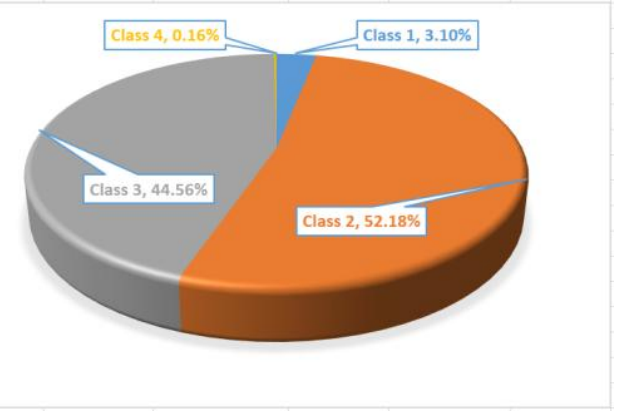

Figure 4. Figure. 4 Distribution of the bridge detection ratio 


\section{Calculation and Analysis}

TABLE III. SMALl AND MEdIUM SPAN BRIDGES UPPER BEAM SHEAR CAPACITY CALCULATION RESULTS

\begin{tabular}{c|c|c|c|c}
\hline \multirow{2}{*}{ Span(m) } & $\begin{array}{c}\text { Middle and } \\
\text { side plate }\end{array}$ & $\begin{array}{c}\text { Calculated } \\
\text { bending moment } \\
\text { of mid- } \\
\text { span(kN.m) }\end{array}$ & $\begin{array}{c}\text { Resistance } \\
(\mathrm{kN} . \mathrm{m})\end{array}$ & $\begin{array}{c}\text { Difference } \\
\text { value of } \\
\text { bending } \\
\text { capacity(\%) }\end{array}$ \\
\hline \multirow{2}{*}{5} & Sideplate & 201.603 & 179.427 & $-11.00 \%$ \\
\cline { 2 - 5 } & Middleplate & 265.410 & 175.436 & $-33.90 \%$ \\
\hline \multirow{2}{*}{6} & Side plate & 268.402 & 203.180 & $-24.30 \%$ \\
\cline { 2 - 5 } & Middleplate & 331.235 & 198.079 & $-40.20 \%$ \\
\hline \multirow{2}{*}{8} & Side plate & 429.719 & 335.611 & $-21.90 \%$ \\
\cline { 2 - 5 } & Middleplate & 482.326 & 329.429 & $-31.70 \%$ \\
\hline \multirow{2}{*}{10} & Side plate & 784.433 & 422.025 & $-46.20 \%$ \\
\cline { 2 - 5 } & Middleplate & 616.421 & 546.149 & $-11.40 \%$ \\
\hline
\end{tabular}

TABLE IV. SMALL AND MEDIUM SPAN BRIDGES UPPER BEAM SHEAR CAPACITY CALCULATION RESULTS

\begin{tabular}{c|c|c|c|c}
\hline \multirow{2}{*}{ Span $(\mathrm{m})$} & $\begin{array}{c}\text { Middle and } \\
\text { side plate }\end{array}$ & $\begin{array}{c}\text { Calculated } \\
\text { bending moment } \\
\text { of pivot(kN) }\end{array}$ & $\begin{array}{c}\text { Resistance } \\
(\mathrm{kN})\end{array}$ & $\begin{array}{c}\text { Difference } \\
\text { value of } \\
\text { bending } \\
\text { capacity }\end{array}$ \\
\hline \multirow{2}{*}{5} & Sideplate & 393.611 & 294.815 & $-25.10 \%$ \\
\cline { 2 - 5 } & Middleplate & 400.126 & 208.066 & $-48.00 \%$ \\
\hline \multirow{2}{*}{6} & Side plate & 409.230 & 300.784 & $-26.50 \%$ \\
\cline { 2 - 5 } & Middleplate & 417.273 & 212.392 & $-49.10 \%$ \\
\hline \multirow{2}{*}{8} & Side plate & 448.854 & 555.232 & $23.70 \%$ \\
\cline { 2 - 5 } & Middleplate & 458.739 & 433.967 & $-5.40 \%$ \\
\hline \multirow{2}{*}{10} & Middleplate & 535.811 & 480.247 & $-10.37 \%$ \\
\cline { 2 - 5 } & Side plate & 269.646 & 282.050 & $4.60 \%$ \\
\hline
\end{tabular}

Substructure: The abutment body of the gravity abutment was mainly built by rubble concrete or mortar rubble materials. The load has enhanced to 2014 highway I level, and even though the abutment body ultimate limit states could satisfy the code requirement, but both the construction of bridge's economic conditions, technical level, such as limit, the foundation safety reserves is very small.

According to the JTG B01-2014, the board height needs increase, then the dead load will increase relatively, so it is bound to add burden to the existing abutment foundation. Through calculation and analysis: the base stress, basal eccentricity can not meet the requirement of the specification.

TABLE V. Calculated Results of The Small and Medium Span BRIDGE SUPERSTRUCTURE

\begin{tabular}{c|c|c|c}
\hline Type & $\begin{array}{c}\text { Raw } \\
\text { height }(\mathrm{cm})\end{array}$ & $\begin{array}{c}\text { New } \\
\text { height }(\mathrm{cm})\end{array}$ & Type of the beam and slab \\
\hline 5m solid plate & 30 & 36 & Reinforced concrete slab \\
\hline 6m solid plate & 30 & 36 & Reinforced concrete slab \\
\hline 8m hollow slab & 40 & 46 & $\begin{array}{c}\text { Reinforced concrete } \\
\text { hollow slab }\end{array}$ \\
\hline 10m hollow slab & 40 & 65 & $\begin{array}{c}\text { Prestressed concrete } \\
\text { hollow slab }\end{array}$ \\
\hline
\end{tabular}

\section{RECONSTRUCTION AND EXPANSION TECHNOLOGY}

\section{A. Upper Beam Slabs}

The paper was in line with "the economy, energy saving, environmental protection, recyclable" principle, analog computation was conducted in order to analyze the reconstruction and expansion technology of the $5 \mathrm{~m}-10 \mathrm{~m}$ small and medium span bridge upper beam slabs. Combined with the detection and evaluation results: except the subordination factor that edge distance of beam-end to abutment capping can not meet the correlation technique requirement of ground motion peak acceleration, the upper beam slab ultimate limit state could not meet the JTG B012014 requirement.

\section{B. Substructure}

The detection results showed that, the $5 \mathrm{~m}-10 \mathrm{~m}$ small and medium span bridge presents sub-structural integrity and the structure-globosity is better. The flexural capacity of the pier body and the main structure strength could meet the correlation technical requirements, while the local member could meet the correlation service requirements. In order to avoid waste and reduce the dismantling quantities, the $5 \mathrm{~m}-10 \mathrm{~m}$ small and medium span bridge substructure had been rebuild for utilization in situ.

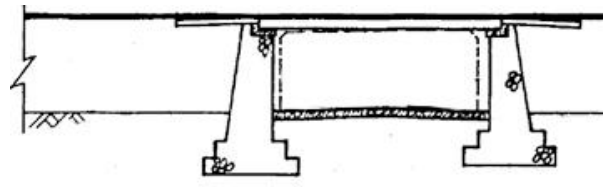

Figure 5. The original abutment design drawing

The distance of simply supported beam-end to pier, abutment cap or bent cap could not meet the aseismatic construction requirement: $\mathrm{a} \geq 70+0.5 \times \mathrm{L} ; \mathrm{L}-$ Calculated span of upper beam slab(m).

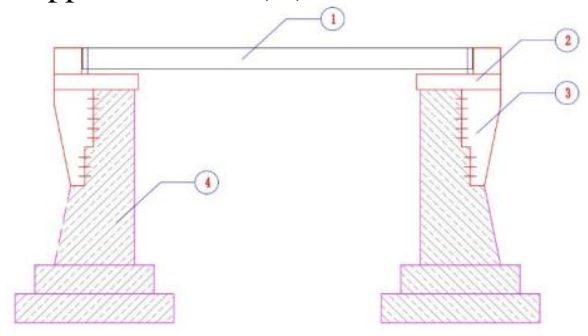

Figure 6. The abutment body reinforcement schematic drawing

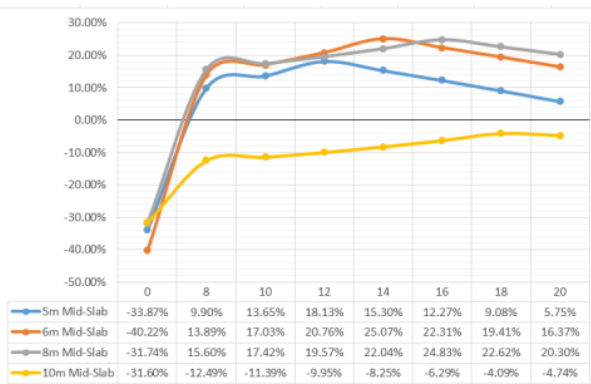

Figure 7. The changing image of the flexural carrying capacity and the mechanical thickness of the bridge pavement 


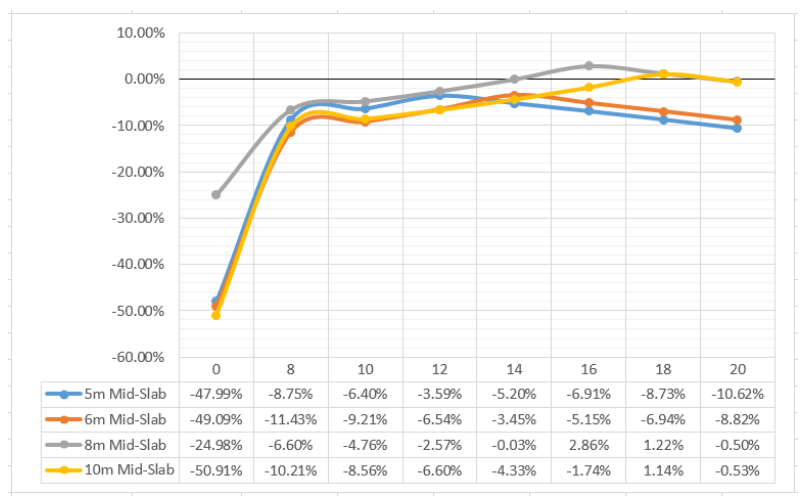

Figure 8 . The changing image of the shear carrying capacity and the mechanical thickness of the bridge pavement

Concentrate: (1)beam and slab; (2)newly build abutment cap; (3)newly build parados; (4)original abutment body.

After the reconstruction of the abutment, the bridge supports were set behind the original abutment, the superstructure and the motor vehicle load effect were balanced with the earth pressure, the abutment body was equal to the axial compressive force. The basal stress was then more even. Take the original $8 \mathrm{~m}$ bridge channel as example, if the newly build $8 \mathrm{~m}$ thickness of slab was being replaced directly, the basement could not meet the force requirement because of the increasing dead load. After the original abutment was reconstructed as Fig. 5, the slab was replaced by $10 \mathrm{~m}$, the basement could meet the force requirement. The basement stress checking calculation results were showed in Tab. 8 .

\section{CONCLUSION}

Upper beam and slab: The working condition of the pavement layer after participating in force can be used for rebuilding and utilization. In order to ensure the participation of stressing reach the optimum condition, the original bridge deck pavement and the hinge joint should be get rid of. After the cross-link reinforcement and the bridge pavement bar-mat reinforcement were added, the hinge joint and the bridge floor concrete pavement layer were overall casted. When the bridge pavement layer participating in the overall stressing of the upper beam slab, it has preferable influence on the flexural carrying capacity, and the efficacious mechanical thickness is $12-16 \mathrm{~cm}$, and it presents increase trend with the increase of the increasing span. While it would decrease when the mechanical thickness exceed the efficacious value.

Substructure: The economic and the society of the affect region of Shandong 1\# expressway have got rapid improvement, the urbanization concentration significantly, the existing structure has not effectively meet the requirements of regional integrated transportation system, especially the about $10 \mathrm{~m}$ channel and the separated interchange needs all demolition reconstruction for 2 holes or porous separation overpass. In view of the simplesupported beam end to the edge of pier, abutment capping or bent cap can not meet the requirement of the aseismatic measures, the existing pier and cap could be dismantled to satisfy the requirement of aseismatic measures. Which it can effectively combine the existing working condition requirements for new construction, reinforcement and classification of disposal. The small span bridge reconstruction and Eexpansion technology has the specialty of short construction period, small effects, convenient for keeping traffic and meeting the demand of basic functions enables it with a large popularize prospect.

\section{REFERENCES}

[1] Highway Engineering Technique Standard (JTG B01-2003)

[2] Highway Engineering Technique Standard (JTG B01-2014)

[3] ZHENG Fei, SUN Ri-shuang, GUO Bao-lin. Comparision and Analysis of Bridge Load Test Standard in China and Czechoslovakia. COMMUNICATIONS STANDARDIZATION, 2007, 11: 28-30. 
TABle VI. Flexural Capacity Calculating Results of the Small and Medium Span Bridge Upper Beam Slab After ReConstruction

\begin{tabular}{|c|c|c|c|c|c|}
\hline $\begin{array}{l}\text { Whether the cast-in place } \\
\text { layer participate in the force }\end{array}$ & $\operatorname{Span}(m)$ & Middle and side plate & $\begin{array}{l}\text { Calculated bending moment of } \\
\text { mid-span(kN.m) }\end{array}$ & Resistance(kN.m) & $\begin{array}{r}\text { Difference value of } \\
\text { bending capacity }(\%)\end{array}$ \\
\hline \multirow{8}{*}{ No } & \multirow{2}{*}{5} & Sideplate & 201.611 & 179.434 & $-11.00 \%$ \\
\hline & & Middleplate & 265.420 & 175.443 & $-33.90 \%$ \\
\hline & \multirow{2}{*}{6} & Side plate & 268.478 & 203.238 & $-24.30 \%$ \\
\hline & & Middleplate & 331.265 & 198.096 & $-40.20 \%$ \\
\hline & \multirow{2}{*}{8} & Side plate & 429.733 & 335.621 & $-21.90 \%$ \\
\hline & & Middleplate & 482.321 & 329.425 & $-31.70 \%$ \\
\hline & \multirow{2}{*}{10} & Side plate & 784.408 & 422.012 & $-46.20 \%$ \\
\hline & & Middleplate & 616.410 & 546.139 & $-11.40 \%$ \\
\hline \multirow{8}{*}{$\begin{array}{l}\text { The cast-in-place layer } \\
\text { participate in the force at } \\
8 \mathrm{~cm}\end{array}$} & \multirow{2}{*}{5} & Side plate & 245.367 & 298.612 & $21.70 \%$ \\
\hline & & Middleplate & 241.509 & 219.773 & $-9.00 \%$ \\
\hline & \multirow{2}{*}{6} & Side plate & 280.291 & 292.624 & $4.40 \%$ \\
\hline & & Middleplate & 275.056 & 228.296 & $-17.00 \%$ \\
\hline & \multirow{2}{*}{8} & Side plate & 423.633 & 417.702 & $-1.40 \%$ \\
\hline & & Middleplate & 417.222 & 360.897 & $-13.50 \%$ \\
\hline & \multirow{2}{*}{10} & Middleplate & 784.481 & 674.654 & $-14.01 \%$ \\
\hline & & Side plate & 616.457 & 691.048 & $12.10 \%$ \\
\hline
\end{tabular}

TABLE VII. Shear CAPacity Calculating Results of the SMall and Medium SPan Bridge UpPer Beam Slab After ReConstruction

\begin{tabular}{|c|c|c|c|c|c|}
\hline $\begin{array}{l}\text { Whether the cast-in place layer } \\
\text { participate in the force }\end{array}$ & $\operatorname{Span}(\mathrm{m})$ & Middle and side plate & $\begin{array}{l}\text { Calculated bending moment of } \\
\operatorname{pivot}(\mathrm{kN})\end{array}$ & $\begin{array}{c}\text { Resistance } \\
(\mathrm{kN})\end{array}$ & $\begin{array}{r}\text { Difference value of } \\
\text { bending capacity }(\%)\end{array}$ \\
\hline \multirow{5}{*}{ No } & 5 & Middleplate & 400.132 & 208.069 & $-48.00 \%$ \\
\hline & 6 & Side plate & 409.222 & 300.778 & $-26.50 \%$ \\
\hline & \multirow{2}{*}{8} & Side plate & 448.761 & 555.117 & $23.70 \%$ \\
\hline & & Middleplate & 458.752 & 433.979 & $-5.40 \%$ \\
\hline & 10 & Middleplate & 535.803 & 462.398 & $-13.70 \%$ \\
\hline \multirow{6}{*}{$\begin{array}{l}\text { The cast-in-place layer } \\
\text { participate in the force at } 8 \mathrm{~cm}\end{array}$} & 5 & Middleplate & 400.107 & 264.871 & $-33.80 \%$ \\
\hline & \multirow{2}{*}{6} & Side plate & 381.901 & 356.314 & $-6.70 \%$ \\
\hline & & Middleplate & 417.233 & 269.533 & $-35.40 \%$ \\
\hline & \multirow{2}{*}{8} & Side plate & 448.086 & 634.938 & $41.70 \%$ \\
\hline & & Middleplate & 491.101 & 525.969 & $7.10 \%$ \\
\hline & 10 & Middleplate & 535.883 & 169.339 & $-68.40 \%$ \\
\hline
\end{tabular}

TABLE VIII. SHEAR CAPACITY CALCULATING RESULTS OF THE SMALL AND MEDIUM SPAN BRIDGE SUPERSTRUCTURE

\begin{tabular}{|c|c|c|c|c|c|c|}
\hline Program & Effect combination & $\begin{array}{l}\text { Checking } \\
\text { computation } \\
\text { contents }\end{array}$ & $\begin{array}{c}\text { Basement } \\
\text { maximum } \\
\text { compressive } \\
\text { stress pmax }(\mathrm{kPa})\end{array}$ & $\begin{array}{c}\text { Bearing capacity } \\
\text { admissible value } \\
\text { of the foundation } \\
\gamma \mathrm{R}[\mathrm{fa}](\mathrm{kPa})\end{array}$ & Whether it meets & $\begin{array}{l}\text { Working } \\
\text { condition }\end{array}$ \\
\hline \multirow{4}{*}{$\begin{array}{l}\text { The program of } \\
\text { changing } 8 \mathrm{~m} \text { slab }\end{array}$} & \multirow{2}{*}{$\begin{array}{l}\text { Long-term effect } \\
\text { combination }\end{array}$} & Mean stress & 134.6 & 193.6 & Yes & - \\
\hline & & Maximum stress & 219.6 & 193.6 & No & $\begin{array}{l}\text { Minimum axial } \\
\text { force }\end{array}$ \\
\hline & \multirow[b]{2}{*}{$\begin{array}{l}\text { Short-term effect } \\
\text { combination }\end{array}$} & Mean stress & 134.6 & 193.6 & Yes & - \\
\hline & & Maximum stress & 225.7 & 242 & Yes & $\begin{array}{c}\text { Minimum } \\
\text { bending momen }\end{array}$ \\
\hline \multirow{4}{*}{$\begin{array}{l}\text { The program of } \\
\text { changing } 10 \mathrm{~m} \\
\text { slab }\end{array}$} & \multirow{2}{*}{$\begin{array}{l}\text { Long-term effect } \\
\text { combination }\end{array}$} & Mean stress & 167.5 & 193.6 & Yes & 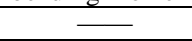 \\
\hline & & Maximum stress & 176.7 & 193.6 & Yes & $\begin{array}{l}\text { Minimum axial } \\
\text { force }\end{array}$ \\
\hline & \multirow{2}{*}{$\begin{array}{l}\text { Short-term effect } \\
\text { combination }\end{array}$} & Mean stress & 167.5 & 193.6 & Yes & - \\
\hline & & Maximum stress & 176.7 & 242 & Yes & $\begin{array}{l}\text { Minimum axial } \\
\text { force }\end{array}$ \\
\hline
\end{tabular}

